\title{
An Investigation Of The Determinants Of BT's Debt Levels From 1998-2002: What Does It Tell Us About The Optimal Capital Structure?
}

Richard J. Fairchild, (Email: mnsrf@bath.ac.uk), University of Bath, UK

\begin{abstract}
Over the period 1998-2001, British Telecom (BT) dramatically increased its debt levels, from $£ 4.8 b n$ in 1998 to $£ 31$ bn in 2001. This was accompanied by a dramatic decrease in the firm's share price.

Subsequent pressure from analysts and investors induced BT to use a rights issue to substantially reduce debt in 2002 (from £31bn to £18.4bn). However, the share price has continued to fall, but not so dramatically.

Hence, BT provides an ideal case study of the effects of capital structure on firm value. In this case study, we will consider such questions as:

a) Why did BT take on so much debt? Why did it cause firm value to fall, when many capital structure theories suggest a positive relationship between leverage and firm value?

b) Why has the reduction in debt not caused an increase in equity value?

c) Was BT beyond its optimal debt/equity ratio from 1998-2001? Is it still beyond the optimum?

d) Does BT have an optimal capital structure? What is it? Is it static? What are the trade-offs involved?

e) Does BT's case hold lessons for other firms?
\end{abstract}

\section{Introduction}

his paper provides an investigation into BT's (British Telecom's) capital structure policy during the period 1998-2002. By the end of the case study, the reader should be able to relate the experiences of BT to the theoretical literature on the capital structure of the firm, and provide answers to the questions that appear at the end of this section, and again at the end of the case.

The seminal work of Modigliani and Miller (1958) analysed the conditions under which the value of the firm is independent of its capital structure. Their Irrelevance Theorem was based on some strong assumptions (some explicit, and some implicit). Subsequent research has sought to examine the conditions under which a firm's capital structure affects its value. This has mainly involved changing the assumptions behind the MM irrelevance theorem.

If capital structure can affect firm value, the natural question arises; can firms identify an optimal capital structure, that is, a structure that maximises firm value? One way of addressing this issue is to consider a trade-off model that recognises that there are costs and benefits of issuing debt or equity. The optimal capital structure trades-

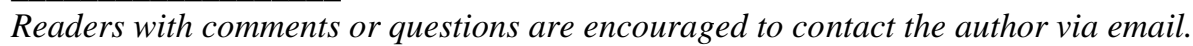


off these costs and benefits to maximise firm value. However, Myers (1998) points out that no golden rule exists for determining a firm's optimal capital structure. He argues that the optimal mix of debt and equity varies from firm to firm, or industry to industry, and therefore should be considered on a case by case basis.

Over the period 1998-2001, British Telecom (BT) dramatically increased its debt levels, from $£ 4.8 \mathrm{bn}$ in 1998 to $£ 31 \mathrm{bn}$ in 2001 . This was accompanied by a dramatic decrease in the firm's share price. Subsequent pressure from analysts and investors induced BT to use a rights issue to substantially reduce debt in 2002 (from $£ 31 \mathrm{bn}$ to $£ 18.4 \mathrm{bn})$. However, the share price has continued to fall, but not so dramatically.

Hence, BT provides an ideal case study of the effects of capital structure on firm value. In this case study, we will consider such questions as;

a) Why did BT take on so much debt? Why did it cause firm value to fall, when many capital structure theories suggest a positive relationship between leverage and firm value?

b) Why has the reduction in debt not caused an increase in equity value?

c) Was BT beyond its optimal debt/equity ratio from 1998-2001? Is it still beyond the optimum?

d) Does BT have an optimal capital structure? What is it? Is it static? What are the trade-offs involved?

e) Does BT's case hold lessons for other firms?

Note that, throughout the case, there will be supplementary questions (in italics) which will help in answering the main questions.

Before we consider the case of BT, we need to consider the capital structure theories in more detail.

\section{Capital Structure Theories}

\section{The Miller and Modigliani Irrelevance Theorem (1958)}

Miller and Modigliani's (MM 1958) seminal work provided the impetus for all of the subsequent research on capital structure. Prior to their studies, corporate finance research had been piecemeal in its approach. MM demonstrated that corporate finance problems can be considered using a modelling approach.

The main result of MM's irrelevance theorem was that, under certain conditions, the value of the firm is independent of its capital structure. They argued that a firm's investment policy has an important effect on firm value, whereas the financing decision is secondary (separability of financing and investment). The theorem was based on the following (explicit and implicit) assumptions; the firm's manager is selfless, always acting in investors' interests (no agency costs); information about the firm is symmetrically distributed between managers and investors; debt is risk-free. MM also ignored the effects of corporate taxes.

According to the discounted cashflow (DCF) model, the value of the firm is the discounted value of all future cashflows. For simplicity, MM assumed perpetuities. Hence, the value of the firm is $V=X / r$, where $X$ represents the perpetual cashflows, and $r$ is the discount rate (or cost of capital).

MM's first contribution was to consider the effects of leverage (the level of debt) on the cost of capital (the investors' required return for investing funds into the business). Both groups of investors (that is, debtholders and equityholders) require a return on their investment. $\mathrm{MM}$ assumed that debt is risk-free, and, therefore, debtholders only require the risk-free rate (the cost of debt equals the risk-free rate).

Debtholders are the first claimants on a firm's cashflows. If debt is risk-free, then equity holders face all of the volatility of the cashflows. Therefore, the cost of equity is higher than the risk-free rate (why?).

At zero leverage, equityholders only face the business risk of the firm. Their required rate of return is termed the cost of unlevered equity. As leverage increases, equityholders face increasing financial risk, as the cashflows to 
equityholders become more volatile. Hence, the cost of levered equity exceeds the cost of unlevered equity, and increases with leverage.

MM next demonstrated that the firm should not be concerned with the cost of debt or the cost of equity in isolation, but instead should be concerned with the overall cost of capital, as measured by the weighted average cost of capital (WACC). Their remarkable result was that, although the cost of debt is lower than the cost of equity, and cost of equity increases with leverage, the WACC is unaffected by leverage.

Next, MM pointed out that the firm should use the WACC, not the cost of debt or cost of equity, as the discount rate in firm valuation. That is, $r=W A C C$, so that $V=X / W A C C$. Since $W A C C$ is independent of the capital structure, then firm value is independent of the capital structure (provided capital structure does not affect $X)$.

\section{Miller and Modigliani-the Effect of Taxes (1961)}

The 1958 irrelevance theorem may have provided a starting point for capital structure theories, but practitioners found it unsatisfactory. It provided no recommendations to firms regarding their optimal capital structure; any capital structure was equally as good. In 1961, MM introduced the effect of taxes into their analysis. The firm pays taxes on net income after deductions for debt interest. Since debt provides a tax shield, firm value increases with debt (ceteris paribus). However, this provided another unsatisfactory result: firm value is maximised by taking on as much debt as possible!

\section{Debt Capacity and Tax Relief}

MM had assumed risk-free debt. However, it is reasonable to assume that beyond a certain level of debt (the debt capacity), debt will no longer be risk-free. If debt is too high, debtholders will also face volatility of returns. (why?).

Beyond the debt capacity, the cost of risky debt exceeds the cost of risk-free debt, and increases with leverage

Since the cost of risky debt increases with leverage beyond the debt capacity, the WACC also increases with leverage. What will happen to firm value if expected cashflows are unaffected?

In practical terms, increasing leverage beyond the debt capacity results in a downgrade of the firm's credit rating, which pushes up the cost of debt. A possible trade-off exists between the tax benefits of debt and the costs of debt beyond the debt capacity. This suggests that there may be an optimal capital structure that minimises WACC and maximises firm value.

Before proceeding to the next section, attempt the following.

1. Present a graph showing firm value as a function of leverage, and (on a separate graph) cost of debt, cost of equity and WACC as a function of leverage, in each of the following cases;
a) MM irrelevance theorem.
b) MM with taxes.
c) Debt capacity and tax relief.

What is the optimal capital structure in each case?

2. Firms often argue that they use a large amount of debt since it is a cheap form of financing. What do they mean? Why is this argument fallacious? 


\section{Agency Costs and Signalling}

The Miller-Modigliani (1958) irrelevance theorem implicitly assumes a) that managers are selfless, purely acting in shareholders' interests, and b) that information is distributed symmetrically between managers and investors regarding the firm and its prospects. In reality, a) a principal-agent relationship may exist, whereby managers have incentives to act in their own self-interests, at the expense of investors, and b) managers may have more information about the firm and its prospects than investors.

In the first case, the capital structure may affect firm value by affecting managerial incentives. In the second case, the capital structure may affect firm value by providing signals about the firm to the investors.

\section{Agency Models}

Jensen and Meckling (1976) were the pioneers of agency cost modelling in relation to the capital structure. They considered a manager who gains utility from both the wealth he derives from the firm, and the private benefits he gains. JM assumed a direct trade-off between firm value and managerial private benefits. Every pound that the manager takes to private benefits represents a pound reduction in firm value.

The capital structure affects the manager's incentives and hence firm value as follows. Leverage reducing capital structure changes (more outside equity, less debt) imply that the manager has a lower equity stake. This induces him to take more perquisites, which reduces firm value. On the other hand, leverage increasing capital structure changes (less outside equity, more debt) imply that the manager has a higher equity stake. This induces him to take less perquisites, which increases firm value.

Hence, for JM, the benefit of debt is that it increases the manager's fractional ownership of the firm, inducing him to take less perquisites, which increases firm value. However, JM consider the manager's incentives to take riskier value-reducing projects (risk-shifting) as debt increases. By trading off these benefits (increased managerial equity ownership) and costs of debt (risk-shifting), JM obtain an optimal (value maximising) capital structure.

Jensen (1986) considers the problems of free cashflow. Free cashflow is the remaining cashflow after the firm has invested in all of the available positive NPV projects. Since only negative NPV projects remain, the free cashflow should be returned to investors in the form of dividends or debt payments. However, empire-building managers may have an incentive to invest it in the negative NPV projects. For Jensen (1986), debt is beneficial by committing the firm to debt interest payments, thus reducing the free cashflow at managements disposal. Jensen uses the free cashflow argument to relate the level of debt to the life-cycle of the firm. He predicts that young firms, with many positive growth opportunities available should have (high or low?) levels of debt, while mature, stagnant firms, with very few growth opportunities, should have (high or low?) levels of debt.

Stulz (1990) develops a free cashflow model. He derives an optimal level of debt which provides just sufficient cashflow to take all of the positive NPV projects, while eliminating the possibility of taking the negative NPV projects.

Dewatripont and Tirole (DT 1991) consider the disciplining role of debt. They develop a model of managerial moral hazard, where firm profit is affected by an unobservable managerial effort level. The manager dislikes high levels of effort.

DT analyse the income rights and control rights associated with debt and equity. Since debtholders have control if the firm does badly (that is, liquidation rights), high levels of debt induce a higher managerial effort level, and higher firm value. However, too much debt might lead to excessive interference in the firm. 


\section{Signalling}

Under conditions of asymmetric information between managers and investors, capital structure may provide signals, which affect firm value. We will consider 3 models (Myers and Majluf 1984, Ross 1977, and Leland and Pyle 1977).

Myers and Majluf (1984) consider the signalling role of equity issuance. They develop a model in which a firm has a new, positive NPV, investment opportunity. The manager knows the future prospects of his firm, whereas investors do not. Specifically, investors (in the absence of signalling by the manager) form an average expectation of the possibility of a good or bad state for the firm. The manager knows for sure whether the good or bad state is coming.

A 'lemons' problem exists. If the manager knows that the good state is going to happen, then equity is currently undervalued, and he is unwilling to issue it, preferring to pass up the positive NPV project. If he knows that the bad state is going to happen, then equity is currently overvalued, so that he has an incentive to issue it. However, issuing equity to rational investors signals that the bad state is going to happen, and the equity value falls.

Due to this lemons problem, Myers and Majluf (1984) prescribe a pecking order for firms' financing decisions. They suggest that firms should raise investment funds in the following order. Firms should use any retained earnings first. Secondly, they should use debt. Finally, they should issue equity as a last resort.

Ross (1977) considers the signalling role of debt issuance. In his model, managerial quality is private information. If the manager issues debt, and is unable to repay, he faces a utility loss through bankruptcy. A low ability manager will not be able to repay a high level of debt, and will therefore face bankruptcy. A high ability manager will be able to repay a high level of debt. Therefore, the high ability manager has an incentive to issue a high level of debt to separate from a low ability manager. In effect, the high ability manager is using a high debt level to demonstrate his confidence in firm prospects to the market.

Leland and Pyle's (LP 1977) model is analogous to that of Myers and Majluf (1984). In LP, they consider how a manager signals his information regarding the firm's prospects by the amount of equity he retains. If he issues a large amount of equity, thus reducing his own equity stake, the market infers that the firm is facing bad future prospects, and firm value falls. If he issues a small amount of equity, and retains a large amount, the market infers that the firm is facing good prospects, and firm value increases. Hence, as in the Myers-Majluf (1984) model, the Leland and Pyle (1977) model suggests that the firm would avoid issuing large amounts of equity if possible.

Before moving on to the next section, consider the following question;

According to these agency cost and signalling models, why might a firm wish to issue high levels of debt? Why might a firm wish to issue low levels of debt?

\section{Models that Search for the Optimal Capital Structure}

We have seen that many factors are involved when considering the effects of capital structure on firm value. It is not surprising, therefore, that no 'golden rule' exists to determine a firm's optimal capital structure ${ }^{1}$. The optimal capital structure needs to be considered on a specific firm, or specific industry, basis. Furthermore, the optimal capital structure is not static, but is dynamic. It may vary over time, and may depend on the stage of the firm's life cycle (eg; Jensen's free cashflow argument 1986), and may depend on macroeconomic and competitive conditions.

Damadoran (2001) considers how firms attempt to choose optimal capital structures. He argues that firms should determine the optimal structure by trading off the costs and benefits of debt (give some examples of these?). However, in reality, firms may use one of the following methods; a) choosing debt and equity according to their life

\footnotetext{
${ }^{1}$ In contrast, firms do have a golden, value maximising, investment appraisal rule, ie the net present value (NPV) rule.
} 
cycle. b) Benchmarking against other firms in their industry (what are the problems with this?). c) Strong preference for a type of financing (pecking order theory).

Levy (1998), and Opler et al (1997), have attempted to develop a formula for determining the optimal capital structure. Both methods form a type of sensitivity analysis, whereby the value effects of different factors of debt and equity financing are considered. For example, the formula derived by Opler et al (1997) includes the interest tax shield on debt, costs of financial distress and bankruptcy, and business risk. They do not consider agency costs. Levy (1998) takes the same factors as Opler et al (1997), and adds agency costs. Therefore, his list of factors is; interest tax shield on debt, costs of financial distress and bankruptcy, business risk, and agency costs (what important aspect has Levy ignored?).

Having used his formula to derive an optimal structure, Levy (1998) then suggests trying this out in the market to see what happens (why is this dangerous?)!

\section{Optimal Capital Structure: The Case of $\mathbf{B T}^{2}$}

Over the period 1998-2001, British Telecom (BT) dramatically increased its debt levels, from $£ 4.3$ bn in 1998 to $£ 31 \mathrm{bn}$ in 2001 . This was accompanied by a downgrade in BT’s credit rating, and a dramatic decrease in the firm's share price. Subsequently, BT has responded to pressure from analysts and investors to reduce the debt level, from $£ 31$ bn to $£ 18.4$ bn by March 2002. However, the share price has continued to fall, though not so dramatically. Hence, BT provides an ideal case study of the effects of capital structure on firm value, and the incentives behind management's capital structure policy.

\section{The Background}

Until the 1980's, telecommunication services in the UK were provided by the GPO (General Post Office) which enjoyed monopoly powers. The GPO had been a Government department until 1969, when the Post Office Act established the GPO as a public corporation. Under the British Telecommunications Act 1981, British Telecom (BT) itself became a separate public corporation. During the early eighties, the UK telecommunication industry was opened up to increasing competition.

In 1984, BT was the first utility to become a public limited company, issuing $50.2 \%$ of its shares to the public and employees. BT was listed on the London, New York and Tokyo exchanges. In 1991, the Government sold over half of its remaining shares, retaining $22 \%$. In 1997, the new labour government sold its remaining shares.

In 2000, BT succeeded in bidding for 3G mobile licences in the UK and Germany. To finance this, BT dramatically increased its debt level, to $£ 31 \mathrm{bn}$. This resulted in a downgrade in its credit rating by Standard and Poors, from AA+ to A (a drop of 4 levels). Between the start of 2000 and May 2001, BT's share price had fallen by $65 \%$.

BT began dramatic restructuring in 2001. It initiated a rights issue in June 2001. This raised $£ 5.9 \mathrm{bn}$, which was used to ease the massive debt levels. In November 2001, BT demerged from its mobile telecommunications arm, BT Wireless. This resulted in two different companies, BT Group plc and mm02. matically.

In 2002, BT's debt level greatly reduced. The share price and firm value continued to fall, though not so dra-

\section{BT- Financial Review}

\footnotetext{
${ }^{2}$ The data for this section is obtained from Datastream, and from an unpublished MSc dissertation by V. Mahalingham (2002). Mahalingham was supervised in the writing of the dissertation by the author of this paper.
} 
Table 1 summarises BT's 5 year financial position from year-end 31/3/1998 to 31/3/2002.

Table 1: Financial Review of BT: 1998-2002.

\begin{tabular}{|l|c|c|c|c|c|}
\hline \multicolumn{1}{|c|}{} & $\mathbf{1 9 9 8}$ & $\mathbf{1 9 9 9}$ & $\mathbf{2 0 0 0}$ & $\mathbf{2 0 0 1}$ & $\mathbf{2 0 0 2}$ \\
\hline Group Turnover & 15,640 & 16,953 & 18,715 & 20,427 & 20,559 \\
\hline Profit After Tax & 1731 & 3002 & 2045 & $(1863)$ & 1018 \\
\hline Total Debt & 4770 & 4333 & 11004 & 30911 & 18440 \\
\hline Equity (market Value) & 41665 & 65402 & 76454 & 33571 & 24283 \\
\hline Firm Market Value & 46435 & 69735 & 87458 & 64482 & 42723 \\
\hline Interest & 260 & 270 & 319 & 1092 & 1383 \\
\hline Dividends Per Share & $13.32 \mathrm{p}$ & $14.3 \mathrm{p}$ & $15.36 \mathrm{p}$ & $6.17 \mathrm{p}$ & $2 \mathrm{p}$ \\
\hline Taxation & 1488 & 1293 & 897 & 652 & 443 \\
\hline Implied Interest Rate & $5.45 \%$ & $6.23 \%$ & $2.9 \%$ & $3.53 \%$ & $7.5 \%$ \\
\hline
\end{tabular}

First, note that group turnover has consistently increased over the 5 years, albeit with a slower growth rate between 2001 and 2002. Profit after tax increased between 1998 and 1999, but then fell between 1999 and 2000, and again between 2000 and 2001. Indeed, BT Group suffered a loss 2001. Profit partially recovered in 2002.

Two important factors in this table are the levels of taxation and the levels of debt interest. The implied interest rate has been calculated using the levels of debt interest (how has this been calculated?).

How can BT's debt policy possibly explain the profile of tax and debt interest in the period 1998-2002?

The focus of our analysis is BT's capital structure, and the effect on equity and firm value. We observe that the debt level increased dramatically from $£ 4.8 \mathrm{bn}$ in 1998 to $£ 30.9 \mathrm{bn}$ in 2001 , to finance $3 \mathrm{G}$ mobile licences in the UK and Germany. At the same time, the taxation rate dropped dramatically (why?). riod?

BT's credit rating was downgraded dramatically over this period. What happened to interest over this pe-

The market value of equity saw a steady increase from 1998 to 2000. However, the value of equity saw a dramatic decline from 2000 onwards (note that this coincides with the period of increasing debt). Furthermore, total market value fell over this period. Why?

Table 2 focuses on the capital structure. The calculations are based on the figures from table 1 . Table 3 translates the market value of equity into the price per share.

Table 2: BT's Capital Structure: 1998-2002.

\begin{tabular}{|l|c|c|c|c|c|}
\hline & $\mathbf{1 9 9 8}$ & $\mathbf{1 9 9 9}$ & $\mathbf{2 0 0 0}$ & $\mathbf{2 0 0 1}$ & $\mathbf{2 0 0 2}$ \\
\hline \% Debt & 10.3 & 6.2 & 12.6 & 47.9 & 43.2 \\
\hline \% Equity & 89.7 & 93.8 & 87.4 & 52.1 & 56.8 \\
\hline D/E Ratio & 0.11 & 0.07 & 0.14 & 0.92 & 0.76 \\
\hline Loan Rate \% & 5.45 & 6.23 & 2.90 & 3.53 & 7.50 \\
\hline
\end{tabular}

Table 2 allows us to consider BT's capital structure (that is, the percentages of debt and equity, the percentage of debt to total market value, and the debt/equity ratio), rather than the level of debt. The table emphasises that, between 1998 and 2000, the percentage of debt in the capital structure was very low, fluctuating around 10\%. This percentage increased dramatically in 2001 and 2002, and debt almost rose to parity with equity (ie we almost saw $50 / 50$ debt and equity, or, equivalently, a debt/equity ratio of 1). The implied loan rate also increased dramatically.

Table 3: Price per Share: 1998-2002. 


\begin{tabular}{|l|c|c|c|c|c|c|}
\hline & $\mathbf{1 9 9 8}$ & $\mathbf{1 9 9 9}$ & $\mathbf{2 0 0 0}$ & $\mathbf{2 0 0 1}$ & $\mathbf{2 0 0 2}$ & $\mathbf{2 0 0 3}$ \\
\hline Number of Shares (m) & 9119 & 9185 & 9256 & 9299 & 8316 & 8681 \\
\hline Price Per Share (pence) & 457 & 712 & 826 & 361 & 292 & 207 \\
\hline MV of Equity (£m) & 41665 & 65402 & 76454 & 33571 & 24283 & 17970 \\
\hline
\end{tabular}

In addition to considering the market value of equity, one must also consider the number of shares and the price per share. Table 3 demonstrates that, since the number of shares was relatively unchanged over the 5 year period, the profile of the market value of equity is mirrored by the profile of BT's share price. Hence, BT's market value of equity and share price were maximised in the year 2000.

Figure 1 demonstrates the total value of BT group, the value of equity, and the value of debt (the top, middle and bottom lines respectively). It is easily observed that total value increased from 1998-2000 (when the level of debt was low). Beyond 2000, the level of debt increased dramatically, and total firm value, and equity value fell. Figure 1 suggests an optimal debt level for BT.

Figure 1.

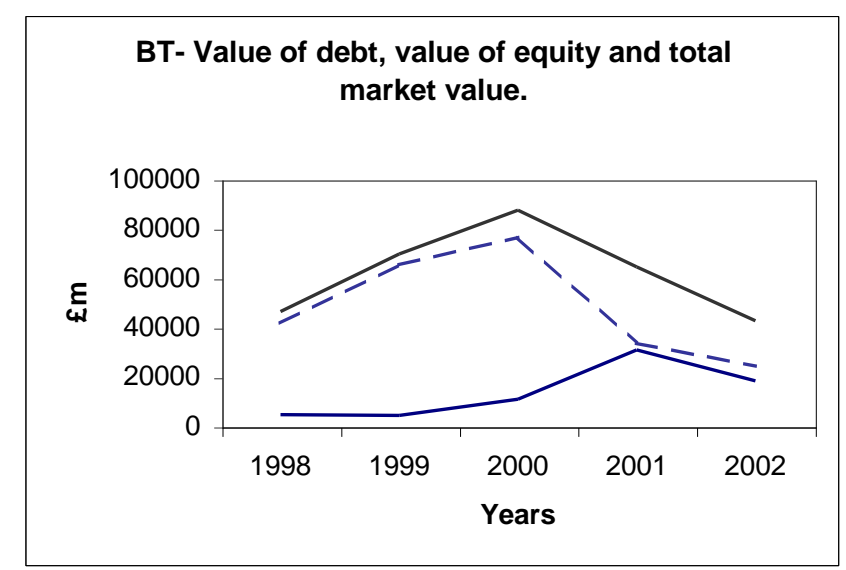

What was BT's optimal debt level in 1998-2002, as suggested by figure 1? What trade-offs might be involved?

Figure 2 demonstrates the percentage of debt (bottom line) and the percentage of equity (top line) in BT's capital structure over the 5 year period, and emphasises the dramatic increase in debt and the dramatic decrease in equity.

Figure 3 demonstrates the effect of the debt/equity ratio on the implied (debt interest) loan rate. Although the loan rate fluctuates over the period 1998-2000 (when the debt/equity ratio is low), it increases dramatically between 2000 and 2002 (when the debt/equity ratio increases towards 1).

How does this contrast with the MM irrelevance theorem? How would figure 3 appear under MM irrelevance?

Figure 2. 


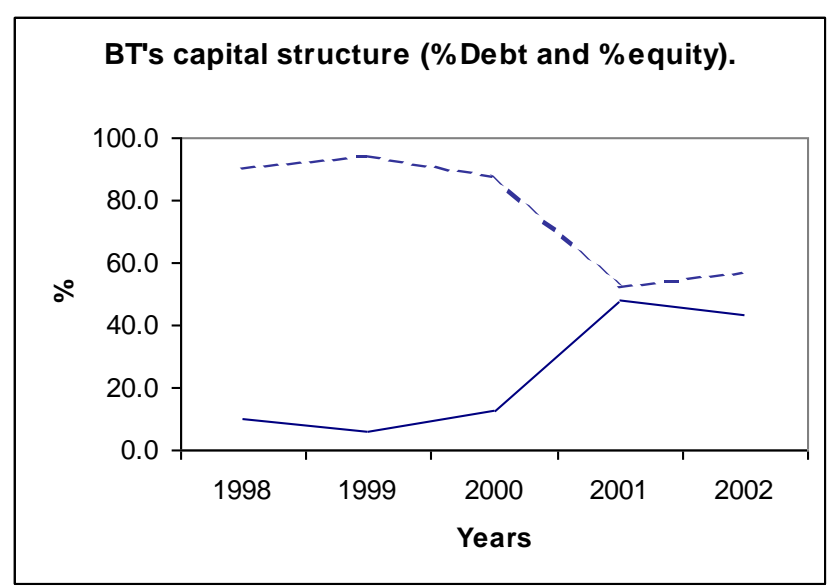

Figure 3.

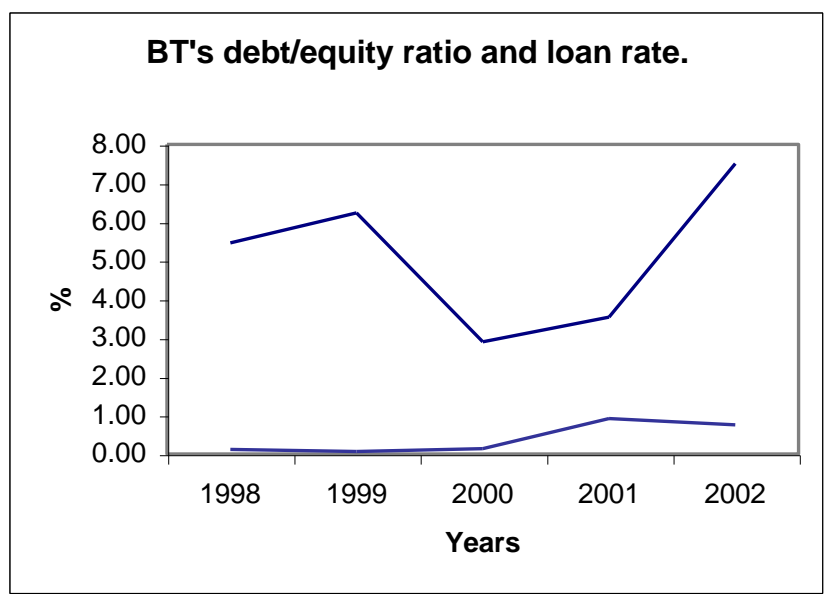

Finally, figure 4 demonstrates firm value as a function of the debt/equity ratio.

What was BT's optimal debt/equity ratio in 1998-2002, as suggested by figure 4?

\section{BT's Optimal Capital Structure?}

We have observed that data on BT's capital structure and market value from 1998-2002 can be used to infer a possible optimal capital structure for BT. The charts demonstrate that firm value (and equity value) increase consistently as debt increases between 1998 and 2000. Firm value is maximised in the year 2000, when debt reached $£ 11$ bn (12.6\% of the capital structure, or, equivalently, a debt/equity ratio of $14 \%$ ). After the year 2000, debt increased dramatically to $£ 31$ bn (approximately $50 \%$ of total capital), and firm value fell.

The charts suggest that BT went beyond its optimal capital structure from the year 2000 .

Figure 4. 


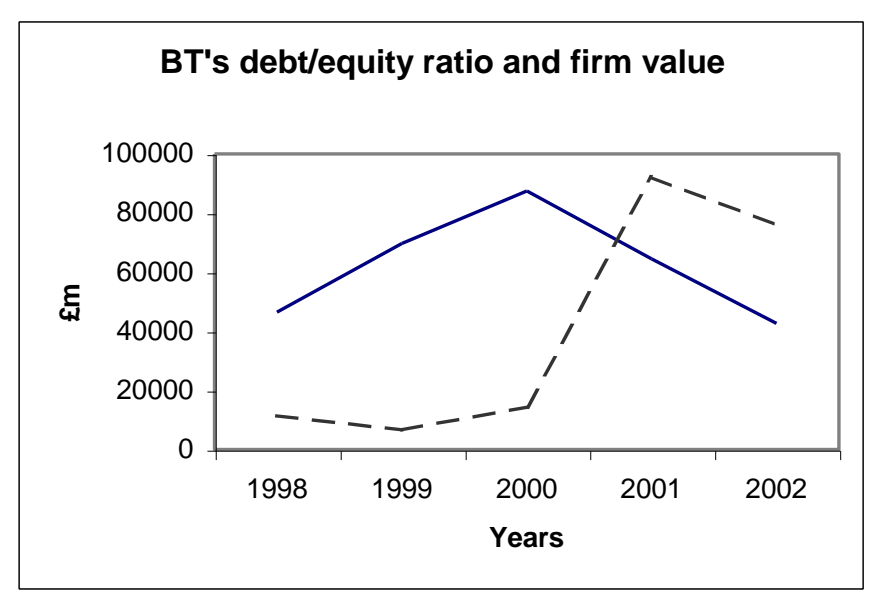

What trade-offs are involved in determining this optimal capital structure? How did BT determine its capital structure policy between 1998 and 2002? Why did BT go beyond the optimal level of debt?

Although there are many factors that influence the effect of the capital structure on firm value, we have noted that they may be considered under the following broad categories; tax relief effects, debt capacity and business risk, agency costs, and signalling.

The data suggests that BT experienced a trade-off between tax relief and debt capacity, with an optimal (value maximising) debt level of $£ 11 \mathrm{bn}$. Throughout the period, the level of tax consistently reduced as debt increased. However, from chart 3, it can be observed that, as debt increased, the loan rate increased. BT has reached its debt capacity, and further increases beyond this caused a downgrading of its credit rating, with an associated increase in the loan rate.

\section{Why did BT go beyond this optimum?}

Without detailed inside knowledge of the management rationale for such high debt levels, we can only surmise the answer to this question. There may have been several factors involved in the BT debt policy. Fortunately, we are able to appeal to the various capital structure theories to shed some light.

Firstly, it is possible that BT fell into the trap of considering debt as a cheap form of financing (with its low loan rates). Why is this a fallacious view, according to the MM irrelevance theorem?

Secondly, BT may have become focused on the tax relief effect. Initially, they would have observed the increase in firm value as they increased the debt level. When they won the $3 \mathrm{G}$ mobile contract, they may have believed that the increased prospects for the Group had increased their debt capacity. This justified taking large levels of debt to increase the tax shield.

BT possibly had an over-optimistic view of the prospects for 3G, and for the Group as a whole. On observing such large levels of debt, rating agencies downgraded BT. BT had gone beyond its debt capacity.

Besides the simple trade-off between tax relief and debt capacity, there may have been other factors involved in BT's decision to increase debt. From the Jensen and Meckling (1976) model, the management of BT may not have wanted to dilute their own equity stake, since dilution may have reduced managerial effort incentives. The company may have also been attempting to commit to a high effort level, due to the disciplining role of debt (ie the bankruptcy threat). Further, BT may have believed that, if 3G generated large free cash flows, it would be better to 
finance with debt (Jensen 1986).

Signalling considerations may have played an important role in BT's debt policy. It may have been believed that high levels of debt provided a strong signal of BT's confidence in the future (as in Ross 1977), or that issuing equity may have signalled bad future prospects (as in Myers and Majluf 1984, Leland and Pyle 1977). Indeed, when debt reduction measures (from the current $£ 31 \mathrm{bn}$ ) were discussed at the AGM in 2001, one investor suggested increasing debt even further to demonstrate BT's strength! Decreasing debt would be a sign of weakness!

BT may simply have had a preference for debt (as in Myers and Majluf's (1984) pecking order theory). Furthermore, BT may have used the type of model suggested by Levy (1998) or Opler et al (1997). Following Levy's suggestion, they may have been trying out this level of debt, and got it horribly wrong!

Whatever the reasons, it is apparent that BT went beyond its optimal debt-equity ratio after 2000. Analysis of this period suggests an optimal debt level of $£ 11 \mathrm{bn}$. Indeed, BT has taken measures to reduce debt. However, capital structure policies are dynamic, and the optimal capital structure policy needs to be regularly revisited.

\section{Other Players in the Industry}

Damadoran (2001) states that firms often choose their capital structures by benchmarking against other firms in the industry. In this section, we consider two other companies in the telecommunications industry; Deutsche Telekom, and France Telecom.

Their capital structures are as follows;

\section{Deutsche Telekom}

\begin{tabular}{|l|c|c|c|c|c|}
\hline Euros (millions) & $\mathbf{1 9 9 7}$ & $\mathbf{1 9 9 8}$ & $\mathbf{1 9 9 9}$ & $\mathbf{2 0 0 0}$ & $\mathbf{2 0 0 1}$ \\
\hline Debt & 44938 & 39933 & 42337 & 60357 & 67031 \\
\hline Equity (Mkt Value) & 47486 & 76875 & 213842 & 97250 & 81436 \\
\hline Firm mkt Value & 92424 & 116808 & 256179 & 157607 & 148467 \\
\hline \% Debt & 48.8 & 34.2 & 16.5 & 38.3 & 45.1 \\
\hline D/E ratio & 0.946 & 0.519 & 0.198 & 0.62 & 0.82 \\
\hline
\end{tabular}

France Telecom

\begin{tabular}{|l|c|c|c|c|c|}
\hline Euros (millions) & $\mathbf{1 9 9 7}$ & $\mathbf{1 9 9 8}$ & $\mathbf{1 9 9 9}$ & $\mathbf{2 0 0 0}$ & $\mathbf{2 0 0 1}$ \\
\hline Debt & 16009 & 15145 & 17163 & 63254 & 67504 \\
\hline Equity (Mkt Value) & 33280 & 69353 & 134532 & 106093 & 51807 \\
\hline Firm mkt Value & 49289 & 84498 & 151695 & 169347 & 119311 \\
\hline \% Debt & 32.5 & 17.9 & 11.3 & 37.4 & 56.6 \\
\hline D/E ratio & 0.48 & 0.22 & 0.13 & 0.60 & 1.30 \\
\hline
\end{tabular}

How do these tables suggest benchmarking in the telecommunications industry? What optimal capital structure do the tables suggest for Deutsche Telekom and France Telecom? How does this compare with BT?

\section{Conclusion}

We have investigated BT's capital structure policy during the period 1998-2002. Consideration of this case in conjunction with the various capital structure theories has allowed us to address the following questions; 
capital structure theories suggest a positive relationship between leverage and firm value?

b) Why has the reduction in debt caused a partial recovery in equity value?

c) Was BT beyond its optimal debt/equity ratio from he year 2000 ?

d) Does BT have an optimal capital structure? What is it? Is it static? What are the trade-offs involved for BT?

e) Does BT's case hold lessons for other firms?

\section{References}

1. Damadoran, A. Corporate Finance, Theory and Practice. Wiley International Edition 2001.

2. Dewatripont, M., and J. Tirole. "A Theory of Debt and Equity: Diversity of Securities and Manager-Shareholder Congruence.” Quarterly Journal of Economics, 1027-1053.

3. Jensen, M. (1986). "Agency Costs of Free Cash Flow, Corporate Finance and Takeovers.” American Economic Review 76, 323-339.

4. Jensen, M., and W.Meckling. (1976). "Theory of the Firm: Managerial Behavior, Agency Costs, and Capital Structure." Journal of Financial Economics 3, 305-360.

5. Leland, H., and D. Pyle. (1977). "Information Asymmetries, Financial Structure, and Financial Intermediation.” Journal of Finance 32, 371-388.

6. Levy, H. Principles of Corporate Finance. South-Western College Publishing. 1998.

7. Mahalingham, V. (2002). "Capital Structure Strategies of BT Group PLC and its Impact on its Firm Value." Unpublished MSc Dissertation; School of Management, University of Bath, UK.

8. Modigliani, F., and M. Miller. (1958). "The Cost of Capital, Corporation Finance and the Theory of Investment." American Economic Review 48, 261-297.

9. Myers, S. "Still Searching for Optimal Capital Structure," in The Revolution in Corporate Finance, edited by J.M. Stern and D.H. Chew Jr. (Blackwell Publishers 1998).

10. Myers, S., and N. Majluf. (1984). "Corporate Financing and Investment Decisions when Firms have Information that Investors do not have." Journal of Financial Economics 13, 187-221.

11. Opler, T., Saron, M., and Titman, S. (1997) "Corporate Liability Management." Mimeo.

12. Ross, S. (1977). "The Determinants of Financial Structure: The Incentive Signalling Approach.” Bell Journal of Economics 8, 23-40.

13. Stulz, R. (1990). "Managerial Discretion and Optimal Financing Policies.” Journal of Financial Economics 26, 3-27. 